\author{
Natalia Iershova \\ National Technical University "Kharkiv Polytechnical Institute", Kharkiv, Ukraine \\ E-mail: iershova.ny@gmail.com \\ ORCID: http://orcid.org/0000-0003-3544-3816 \\ ResearcherID E-9642-2019 \\ Viktoriia Garkusha \\ National Technical University "Kharkiv Polytechnical Institute", Kharkiv, Ukraine \\ E-mail: nikarusj@gmail.com \\ ORCID: http://orcid.org/0000-0003-2643-0642
}

\title{
Functioning of the system of ensuring the economic security of the industrial enterprise: conceptual provisions
}

\begin{abstract}
The purpose of the article is the scientific substantiation and further development of the theoretical foundations and methodology of the system of economic security of an industrial enterprise. Methodology. The methodological bases are the provisions of security theory and the laws of the market economy. In the study the system method was used to reveal the essence of the mechanism of functioning of the economic security system; methods of logic, qualitative analysis and synthesis were used to structure the mechanism of functioning of the economic security system; economic and logical methods were used to establish the nature of the functioning of the economic security system of an industrial enterprise; the integrated method was used to substantiate the concept of "economic security system of an industrial enterprise". Results. Approaches to the functioning of the economic security system of an industrial enterprise in terms of management processes, management objects and elements are proposed. The locus in ensuring the functioning of the economic security system is the mechanism. The classification of methods of economic security management of the enterprise is given. The conceptual bases of functioning of the system of economic safety of the industrial enterprise are developed. A scheme is proposed in order to determine the nature of the functioning of the economic security system of an industrial enterprise, which takes into account the attributes: capabilities, possibilities, desires, interests and aspirations. Practical implications. The practical significance of the obtained results lies in the enrichment of the practice of economic security of an industrial enterprise with scientifically substantiated proposals to improve the functioning of its system. The use of the proposed conceptual provisions and the appropriate algorithm to establish the nature of the economic security system can increase the efficiency of the economic security system in the economic practice of enterprises. Value/originality. The scientific novelty of the obtained results lies in the development and working out of theoretical and methodological principles of functioning of the system of economic security of an industrial enterprise in accordance with the requirements of market situations.
\end{abstract}

\author{
Keywords \\ Economic security, \\ mechanism, conceptual \\ basis, functioning of \\ the economic security \\ system, industrial \\ enterprise
}

JEL: D81, L21, M10

DOI: https://doi.org/10.30525/2500-946X/2021-2-6

\section{Introduction}

Industry plays an important role in ensuring the stable economic growth of any country. For example, in Germany, the share of industry in gross value added is almost $23 \%$, in the Czech Republic 18.7\%, in Poland 14.2\% (UNIDO, 2020). Increasing competition, growing uncertainty and increasing difficulties faced by Ukrainian industrial enterprises lead to the need to use innovative methods in managing their activities. Statistics shows that the growth rate of unprofitable industrial enterprises reach 12.3\% (Ukrstat, 2020). This has a particularly negative impact on their financial and economic condition and the economic situation in Ukraine as a whole. Based on the thesis of the combination of efficiency as a consequence of market relations and enterprise management, industrial enterprises are particularly sensitive to the influence of economic and social factors. An important condition for the sustainable development of an industrial enterprise in the long run is the availability of a relevant knowledge base and its effective use in management through a system of economic security. Today, in world practice, most of the theoretical and methodological provisions of economic security remain controversial and insufficiently covered. There is a lack of research in the theory of economic security, substantiation of the conceptual foundations of building a system of economic security of adequate composition and structure of tasks facing the management of industrial enterprises of Ukraine. The tools for assessing the effectiveness of the economic security system need additional argumentation. The effective functioning of the system of economic security of an industrial enterprise is an indicator of adaptive ability and allows developing and implementing a flexible strategy for its sustainable development. However, enterprises, as a rule, do not have sufficient experience in developing and implementing a system of economic security. It functions in fragments and its main task is to solve current problems. 
The relevance of this study is due to the theoretical and practical significance of issues related to ensuring the functioning of the economic security system of an industrial enterprise. This allows the company's management to be sure that all management influences have achieved their goal and all instructions are followed.

The purpose of the article is the scientific substantiation and further development of the theoretical foundations and methodology of the system of economic security of an industrial enterprise.

\section{The system of economic security of the enterprise}

In the process of economic activity industrial enterprises operate in conditions of fierce competition and make decisions in a state of uncertainty. This causes a high degree of risk of economic activity (Shcarlet, 2007). An effective system of economic security of the enterprise is the integration of two components: ensuring the effectiveness of a set of measures to achieve it and the ability to respond in a timely manner to identified threats from the external and internal environment (Ilyashenko, 2015). The discussion about the structure of the economic security system at the enterprise has led to the presence of a significant number of elements (Vasiliev, 2013). There are differences in scientific views on the objects, the subjects of the system, the principles of formation, etc. (Zachosova, 2016). Changes in the behavior of business structures in accordance with the external conditions of operating require clarification of the elements of the structure of the economic security system. Also, it emphasizes the importance of optimizing the number of functional components in the context of the implementation of the functions of the economic security of the enterprise in combination with the necessary tools (Sherman, 2015). The importance of the mechanism for ensuring the functioning of the economic security system of the enterprise was reported. The mechanism is defined as one of the most important elements of the security system of the enterprise. During the discussions, the components of the mechanism are defined as a set of legislative acts, methods, means by which the achievement of security goals and the solution of the set tasks is ensured (Kvasniy, 2015).

\section{Current approaches to the functioning of the economic security system}

The synopsis of approaches to economic security of the enterprise, in the light of the last scientific researches, indicates an accurate and systematic tendency to its improvement. Research results confirm that the system of economic security is becoming an object of management. This situation is explained by arguments:

- ensuring of economic security requires the use of a significant number of employees working in various departments of the enterprise (Kolpakov, 2007);

- economic security is provided by various resources: personnel, technical, technological, financial, intellectual and others (Kudelya, 2014);

- ensuring of economic security requires constant management influence through the procedures of planning, organizing, motivating, controlling and regulating (Garkusha, 2018);

- needs of proper accounting and analytical support (Iershova, 2016).
As an object of management, economic security is studied using scientific approaches. A systematic approach to the functioning of the economic security system (which is the most common among scientists) involves taking into account the real conditions of the enterprise. In this case, the system of economic security is a subsystem in the system of general management of the enterprise (Danilova, 2020). With the separation of such a subsystem, the overall management system of the enterprise becomes complex and flexible. When developing practical provisions for the organization of economic security of the enterprise, the functional approach becomes relevant (Dub, 2016). According to this approach, ensuring economic security is based on the distribution of functions that must be performed while implementing the tasks. With the help of functional connections among the most important structural units of the enterprise it is possible to describe the activities of the enterprise at the generalized level. The functional approach is complemented by the activity approach (Karkovska, 2018). Based on the activity approach, the zones of responsibility are delineated in accordance with the principle of significance of the objects of protection. Indeed, the functional responsibilities of employees must meet the overall goal to ensure the sustainable and safe development of the enterprise. Changing of the behavior of the enterprise models in a competitive environment has contributed to the development of an integrated approach to ensure the economic security of the enterprise (Moroz and others, 2010). Scientists A. Melikhov and E. Kamyshnikova in their research proposed "the logic of distinguishing between the concepts of ensuring" the economic security of enterprises "and" economic security of enterprises "according to the scheme" activity - the result of activity".

\section{Research methodology}

Issues of ensuring the economic security of industrial enterprises in the chaotic emergence of internal and external threats determine the possibility of achieving sustainable development and increasing the level of competitiveness including the effective functioning of the economic security system. In this study, we proceed from the idea the economic security is an inherent property of the management system of the enterprise. That is, security is a systemic type of economic activity that permeates all management processes, including components of strategy and operational plans. Effective functioning of the economic security system of the enterprise is possible on the basis of an integrated approach using special technologies, methods and tools. The synergistic effect of their use is to achieve a positive end result that is stable and secure operation of the enterprise as an economic system. Approaches to the functioning of the economic security of the enterprise are given in table 1.

The functioning of the system of economic security of the enterprise provides a mechanism that must have clearly defined elements, the scheme of their action and interaction. The structure of the mechanism of economic security of the enterprise consists of several blocks (Figure 1).

Improving of management, forming an effective system of economic security, eliminating unnecessary links, duplicating of communication channels, overcoming resistance in changing is possible through research on the relationship of economic security functions. The 
TABLE 1 Approaches to the functioning of the economic security system of an industrial enterprise

\begin{tabular}{|c|c|}
\hline Approaches & The essence of approaches \\
\hline In terms of management processes & $\begin{array}{l}\text { It is advisable to distinguish the processes of development, implementation and management of the economic } \\
\text { security of the enterprise }\end{array}$ \\
\hline In terms of management objects & $\begin{array}{l}\text { In general, the system of economic security of the enterprise is convenient to divide into separate subsystems } \\
\text { for different objects (resources, activities). Such a division will ensure better and timely management. }\end{array}$ \\
\hline In terms of elements & Such elements include: purpose, objectives, principles, functions, object and subject, tools, methods, regulations \\
\hline
\end{tabular}

Source: developed by the author

implementation of the mechanism of economic security of the enterprise is possible due to some methods. Methods are ways and techniques of influencing the management system of economic security on the managed one at different levels and sections of government (economic security system in general, subsystem, unit, etc.). All methods of economic security are dialectically related to their functions. Methods of economic security function as a holistic system consisting of interacted and interconnected elements, not a separate and independent means of influence (Table 2).

Formalization of methods of economic security management contributes to their transformation into management decisions and allows to ensure their qualitative impact. From the control system to the controlled direct communication channels come the methods of economic security, transformed into management decisions. At the same time, the necessary managerial influence is carried out, which ensures the implementation of operations to ensure the economic security of the enterprise.
The development of a conceptual framework for economic security, its organization and implementation in practice is based on a reasonable set of conceptual, theoretical and applied principles relating to the structure, functions, principles, organizational issues and methods for a particular enterprise (Figure 2).

To ensure the effective functioning of the economic security system of an industrial enterprise, the following tasks must be performed:

- selection of components and development of technology for organizing the functioning of the economic security system;

- management of components of the economic security system, which provide cost optimization;

- development and implementation of adequate methods of economic security for these purposes;

- organization of relevant service work;

- development of information and methodological support for the mechanism of economic security;

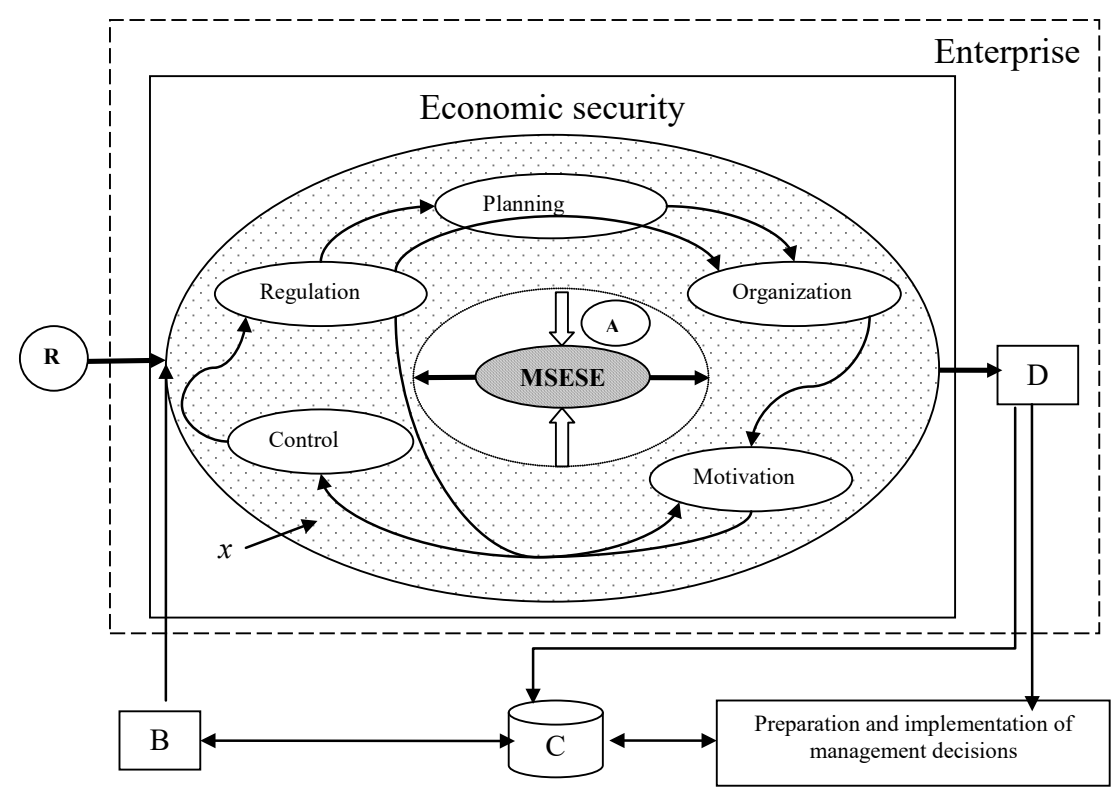

\section{Figure designation 1:}

MSESE - managed system of economic security of the enterprise; A - ways of implementing economic security; $B$ - entrance: internal ideas; $\mathrm{C}-$ system of information collection and storage; $D$ - exit: implemented ideas; $R$ - entrance: external ideas; $x$-economic security subsystem

\begin{tabular}{|l|l|}
\hline$\rightleftarrows$ & feedback \\
\hline & direct connection \\
\hline
\end{tabular}

FIGURE 1 The mechanism of functioning of the system of economic security of an industrial enterprise

Source: developed by the author 
TABLE 2 Classification of methods of economic security management of the enterprise

\begin{tabular}{|c|c|}
\hline Classification features & Essence \\
\hline $\begin{array}{l}\text { Direction of impact } \\
\text { on the managed object }\end{array}$ & $\begin{array}{l}\text { Methods of direct influence (directly affect the managed system: orders, directives, instructions, regulations, etc.). } \\
\text { Methods of indirect influence (create conditions for influencing the managed management system: selection of staff, } \\
\text { formation of psychological climate, etc.). }\end{array}$ \\
\hline $\begin{array}{l}\text { The method of taking } \\
\text { into account the interests } \\
\text { of employees in the field } \\
\text { of economic security }\end{array}$ & $\begin{array}{l}\text { Material methods of influence (take into account the property and financial interests of employees). } \\
\text { Moral methods of influence (aimed at increasing socio-economic activity; include ethical norms, moral incentives, etc.). } \\
\text { Methods of government influence (aimed at streamlining the functions and responsibilities of employees of the } \\
\text { economic security system, rationing and regulation of their activities: staff lists, contracts, orders, reprimands, etc.). }\end{array}$ \\
\hline Form of influence & $\begin{array}{l}\text { Quantitative (estimates, calculations, prices, budget, material incentives, etc.). } \\
\text { Qualitative (indications, instructions, moral incentives, etc.). }\end{array}$ \\
\hline The nature of the impact & $\begin{array}{l}\text { Economic (due to various economic factors through which the collective and individual satisfaction of needs at all levels } \\
\text { of communications management is achieved). } \\
\text { Technological (provide the impact on employees of the economic security system through documents that define } \\
\text { the technology of processes. } \\
\text { - Socio-psychological (a set of psychological ways of influencing interpersonal relationships and connections, social } \\
\text { processes of the team. } \\
\text { - Administrative (cover such methods of influence as: organizational, administrative and disciplinary). }\end{array}$ \\
\hline
\end{tabular}

Source: developed by the author

- setting deadlines for the introduction of information and methodological support for the mechanism of economic security;

- creation of an effective system of control over compliance with the requirements for the organization of economic security.

The functioning of the system of economic security of an industrial enterprise is influenced by factors: capacity, opportunities, desires, interests and aspirations. The influence of these factors determines the nature of the functioning of the economic security system of an industrial enterprise: active, passive (Figure 3).

Lack of (-) capacity, opportunities, desires, interests and aspirations determine the passive nature of the system of economic security of an industrial enterprise. The presence of (+) these arguments determine the degree of interest of the owner, management and individual employees in the development of quality parameters of the enterprise from the standpoint of security. Based on the study, we propose to consider the system of economic security of industrial enterprises (SEB) as an integrated system of services and departments of the enterprise, which on the basis of a certain mechanism, tools and methods forms and coordinates a system of management decisions to ensure safe development. Such activity is a functional support, a service function of the management system of the enterprise to ensure or enhance its efficiency.

\section{Findings}

From the point of view of the integrated approach the system of economic safety of the industrial enterprise is integrated into a complex of management of the enterprise. SEB is defined as consisting of interrelated elements that are developed and used by the owner or management to ensure the sustainable development of

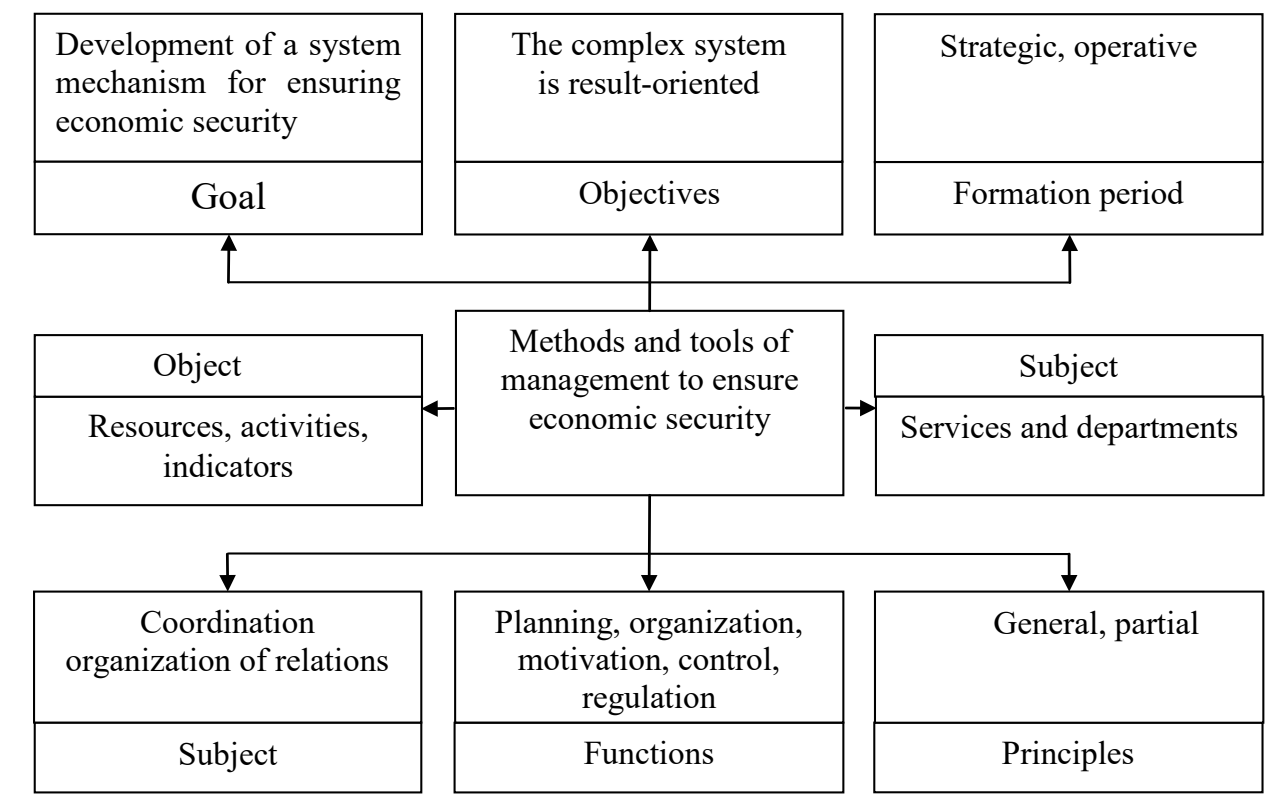

FIGURE 2 Conceptual bases of functioning of the system of economic safety of the industrial enterprise 


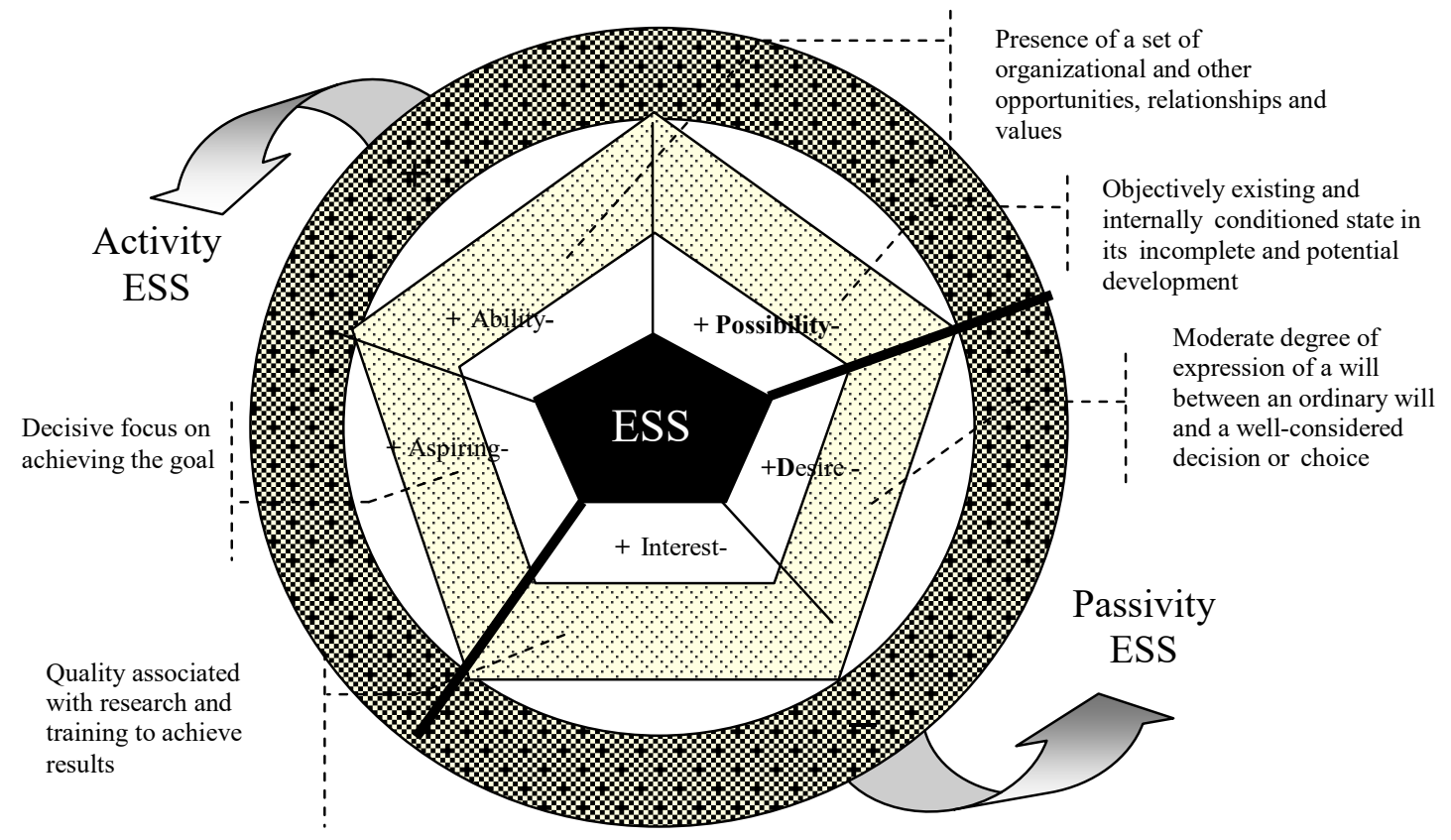

Factors influencing the functioning of the economic security system (ESS). Condition causes of the ESS.

The nature of ESS, which affects the efficiency of management activities.

FIGURE 3 Determining the nature of the functioning of the economic security system of an industrial enterprise

Source: developed by the author

the enterprise. The locus of functioning of the economic security system is a mechanism that is implemented through methods. Formalization of methods of economic security management contributes to their transformation into management decisions and allows to ensure their qualitative impact. The nature (active/passive) of the system of economic security of an industrial enterprise is determined by certain factors.

\section{Conclusions}

The development of the conceptual basis for the functioning of the system of economic security of an industrial enterprise is based on a reasonable set of conceptual-theoretical and applied principles. They relate to the structure, functions, principles, organizational issues and methods for a particular enterprise. The practice of industrial enterprises shows that the need of the effective functioning of the economic security system arises in connection with changes in the external and internal environments of the organization. Therefore, the effective functioning of the economic security of the enterprise is possible on the basis of an integrated approach using special technologies, methods and tools. The approaches to the functioning of the system of economic security of an industrial enterprise proposed in the research are differentiated in terms of management processes, management objects, elements. This provides an opportunity to develop the theoretical foundations of economic security of the enterprise.

We consider the mechanism as a concept of functioning of the system of economic security of an industrial enterprise. Practical implementation of the mechanism is provided by some methods. The proposed classification of methods of economic security management of the enterprise provides an opportunity to obtain a synergistic effect from their use. The result is the achievement of a positive final result, stable and secure operation of the enterprise as an economic system. The number and types of methods to be used are determined by the responsible person or management, taking into account the specifics of the enterprise.

The variety of economic relations in which the company is in the process of its economic activity, leads to a large number of factors influencing the economic security of its activities. Therefore, we have identified the tasks that determine the practical effectiveness of the economic security system of an industrial enterprise. We note that the structure of the economic security system of a particular industrial enterprise should be aimed at promoting ordered, economic, efficient activities in accordance with the mission and purpose of the enterprise; holding to regulations, as well as orders and instructions of management. The main conclusion in this regard is that the combination of principles and methods of organizing the functioning of the economic security system in an industrial enterprise should be implemented in the form of an order on economic security policy in practice. In such a document a separate section should define the form of organization and type of organizational structure of the apparatus of economic security; communication system with other divisions of the enterprise; formation of a system of protection of confidential information in the system of economic security; the monitoring of the reliability, efficiency, quality of the economic security system. 


\section{References}

[1] Danilova, E. I. (2020). Kontseptsiia systemnoho pidkhodu do upravlinnia ekonomichnoiu bezpekoiu pidpryiemstva [The concept of a systematic approach to the management of economic security of the enterprise]. Vinnytsia: Yevropeiska naukova platforma. (in Ukrainian)

[2] Dub, B. S. (2016). Systema ekonomichnoi bezpeky pidpryiemstva: poniattia ta struktura [System of economic security of the enterprise: concept and structure]. Upravlinnia proektamy ta rozvytok vyrobnytstva, 4(60): 5-18. (in Ukrainian)

[3] Cherep, A.V. \& Lubenets, I. O. (2010). Kontseptualni zasady ekonomichnoi bezpeky pidpryiemstv [Conceptual principles of economic security of enterprises]. Visnyk Zaporizkoho natsionalnoho universytetu, 1(5): 63-66. (in Ukrainian)

[4] Iershova, N. Yu. (2016). Intehrovana systema oblikovo-analitychnoho zabezpechennia protsesiv rozrobky ta realizatsii stratehii rozvytku pidpryiemstva [Integrated system of accounting and analytical support of processes of development and realization of strategies of development of the enterprise]. E-source: http://repository.kpi.kharkov.ua/bitstream/ KhPI-Press/23806/1/ (in Ukrainian)

[5] Iershova, N. Iu. (2015). Metodychnyi pidkhid do formuvannia informatsii v systemi stratehichnoho upravlinskoho obliku z metoiu pidvyshchennia ekonomichnoi bezpeky subiektiv hospodariuvannia [Methodical approach to the formation of information in the system of strategic management accounting to increase the economic security of economic entities]. Naukovyi visnyk mizhnarodnoho humanitarnoho universytetu, 10: 276-281. (in Ukrainian)

[6] Illiashenko, O. V. (2015). Pobudova systemy ekonomichnoi bezpeky pidpryiemstva: pryntsypovi polozhennia [Building a system of economic security of the enterprise: principles]. Efektyvna ekonomika, 11. E-source: http://www.economy.nayka.com.ua/?op=1\&z=4497 (in Ukrainian)

[7] Harkusha, V. O. \& Iershova, N. Iu. (2018). Teoretychno-metodychni zasady formuvannia ekonomichnoi bezpeky pidpryiemstva [Theoretical and methodological principles of formation of economic security of the enterprise]. Prychornomorski ekonomichni studii, 27(1): 106-112. (in Ukrainian)

[8] Karkovska, V.Ya. (2018). Osoblyvosti upravlinnia systemoiu finansovo-ekonomichnoi bezpeky pidpryiemstva [Features of management of the system of financial and economic security of the enterprise]. Visnyk lvivskoho politekhnichnoho universytetu. E-source: http://ena.lp.edu.ua:8080/bitstream/ntb/22399/1/16-Karkovska-31-32.pdf (in Ukrainian)

[9] Kolpakov, P. A. (2007). Konceptual'nye osnovy ekonomicheskoj bezopasnosti firmy [Conceptual bases of economic safety of firm]. Moscow: MGU. (in Russian)

[10] Kvasnii, L. H., Popivniak, O. M, \&Shcherban, O. Ya. (2015). Stratehichne i taktychne planuvannia diialnosti pidpryiemstva yak osnovni skladovi mekhanizmu zabezpechennia yoho ekonomichnoi bezpeky [Strategic and tactical planning of the enterprise as the main components of the mechanism of ensuring its economic security]. Naukovyi visnyk Mykolaivskoho derzhavnoho universytetu imeni V. O. Sukhomlynskoho, 1: 48-53. (in Ukrainian)

[11] Kudelia, L. V. (2014). Formuvannia kontseptsii zabezpechennia ekonomichnoi bezpeky pidpryiemstv [Formation of the concept of economic security of enterprises]. Naukovyi visnyk Khersonskoho derzhavnoho universytetu, 5(2): 125-128. (in Ukrainian)

[12] Moroz, O. V., Karachyna, N. P. \& Shyian, A. A. (2010). Kontseptsiia ekonomichnoi bezpeky suchasnoho pidpryiemstva [The concept of economic security of a modern enterprise]. Vinnytsia: VNTU. (in Ukrainian)

[13] Sherman, Ye. M. (2015). Orhanizatsiino-ekonomichnyi mekhanizm rozvytku pidpryiemstv kharchovoi promyslovosti [Organizational and economic mechanism of development of food industry enterprises]. Kherson. (in Ukrainian)

[14] Shkarlet, S. M. (2007). Ekonomichna bezpeka pidpryiemstva: innovatsiinyi aspekt [Economic security of the enterprise: innovative aspect]. Kyiv: Knyzhkove vyd-vo NAU. (in Ukrainian)

[15] Vasyliev, O. V. (2013). Formuvannia systemy upravlinnia ekonomichnoiu bezpekoiu promyslovykh pidpryiemstv [Formation of the management system of economic security of industrial enterprises]. Ekonomichnyi analiz, 14(2): 138-145. (in Ukrainian)

[16] UNIDO. The Industrial Competitiveness of Nations Looking back, forging ahead. Competitive Industrial Performance Report. E-source: https://stat.unido.org/content/publications/competitive-industrial-performance-report-2020

[17] Zachosova, N. V. (2016). Formuvannia systemy ekonomichnoi bezpeky finansovykh ustanov [Formation of the system of economic security of financial institutions]. Cherkasy: PP Chabanenko Yu. A. (in Ukrainian) 